\title{
Effect of zinc on the immune response and production performance of broilers: a meta-analysis
}

\author{
Cecep Hidayat ${ }^{1,2}$, Sumiati ${ }^{3}$, Anuraga Jayanegara ${ }^{3, *}$, and Elizabeth Wina ${ }^{2}$
}

* Corresponding Author: Anuraga Jayanegara Tel: +62-251-8626213, Fax: +62-251-8626213,

E-mail: anuraga.jayanegara@gmail.com

1 Graduate School of Nutrition and Feed Science, Faculty of Animal Science, IPB University, Bogor 16680, Indonesia

2 Indonesian Research Institute for Animal Production,

Ciawi Bogor 16720, Indonesia

${ }^{3}$ Department of Nutrition and Feed Technology,

Faculty of Animal Science, IPB University, Bogor 16680, Indonesia

ORCID

Cecep Hidayat

https://orcid.org/0000-0002-8856-661X

Sumiati

https://orcid.org/0000-0002-7599-2310

Anuraga Jayanegara

https://orcid.org/0000-0001-7529-9770

Elizabeth Wina

https://orcid.org/0000-0002-9303-7579

Submitted Feb 23, 2019; Revised Apr 3, 2019; Accepted May 14, 2019
Objective: This study performed a meta-analysis of published trials to determine the effects of zinc on the immune response and production performance of broilers.

Methods: A database was built from published literature regarding the addition of zinc forms or doses and their relation to the immune response and production performance of broilers. Different doses or forms of zinc were identified in the database. The recorded parameters were related to the immune response and production performance. The database contained a total of 323 data points from 41 studies that met the criteria. Then, the data were processed for a meta-analysis using a mixed model methodology. The doses or different forms of zinc were considered fixed effects, different studies were treated as random effects, and p-values were used as the model statistics.

Results: An increase in zinc dose increased $(\mathrm{p}<0.05)$ pancreas metallothionein $(\mathrm{MT})$ and zinc concentrations in the plasma, tibia and meat, all in quadratic patterns, but linearly decreased $(\mathrm{p}<0.05)$ the heterophil/lymphocyte $(\mathrm{H} / \mathrm{L})$ ratio. Regarding the different zinc forms, both inorganic and organic zinc increased $(\mathrm{p}<0.05)$ the zinc concentrations in the plasma and tibia, the calcium and phosphorus contents in the tibia, and the antioxidant activity of superoxide dismutase in meat as compared to control. An increase in zinc dose increased average daily gain $(\mathrm{ADG})$ and decreased feed conversion ratio (FCR) following a quadratic pattern $(p<0.05)$. Inorganic and organic zinc decreased $(p<0.05)$ FCR and $H / L$ ratio than that of control, but these two forms were similar for these parameters.

Conclusion: Zinc addition has a positive impact on immunity and broiler production. Zinc can suppress stress and inhibit the occurrence of lipid peroxidation in broilers, and it can also improve ADG, FCR, and the quality of broiler carcasses.

Keywords: Zinc; Immune Response; Production Performance; Broiler

\section{INTRODUCTION}

Zinc is an important nutrient required for broilers [1] and plays three important roles in the body that facilitate biological functions: as a catalyst, regulator and structural constituent [2]. Furthermore, zinc is essential since it serves as a cofactor in more than 240 enzymes and helps to metabolize nutrients, such as carbohydrates and proteins, thus helping to increase growth and reproductive performance [3,4]. In broiler diets, zinc may be used either as organic zinc (e.g., $\mathrm{Zn}$ protein, $\mathrm{Zn}$ amino acid, or $\mathrm{Zn}$ picolinate) or inorganic zinc (e.g., $\mathrm{ZnCl}_{2}, \mathrm{ZnSO}_{4}$, or $\mathrm{ZnO}$ ). The recommended zinc level in broiler diets by the National Research Council (NRC) [5] is $40 \mathrm{mg} / \mathrm{kg}$ of diet, which can be supplemented via inorganic or organic forms.

On the other hand, broiler production in tropical countries is generally suboptimal as indicated by the poor growth performance, suppressed immune function, respiratory disease incidence and high mortality rate [6,7], apparently due to the high ambient temperature 
and relative humidity occurring in the regions. It had been reported that addition of zinc to the diet of broilers reared under heat stress improved the production performance and reduced the feed conversion ratio (FCR) $[8,9]$. This indicates that zinc addition may be more important for broiler production in the tropics in order to minimize the negative effects associated with such high temperature condition.

Zinc improves the immunity of broilers, and several studies have reported that zinc can improve immunity. First, zinc functions as a cofactor of thymulin and induces proliferation and modulates cytokine release [10]. Second, Sajadifar et al [11] reported that zinc has a role as a nonpharmacologic booster of immunity in broiler chicks. Third, zinc acts as an immunostimulator that is able to enhance both the cellular and humoral immune systems [12]. The role of zinc as an enhancer of broiler immunity is necessary because of the number of restrictions on the use of antibiotics in the diet imposed by many countries. However, the doses of zinc needed to improve the broiler immune response differ across reports, with some studies reporting that the required dose is greater than the NRC [5] recommendation and that zinc has the ability to enhance antibody production. Accordingly, the aim of the current study was to determine the effect of zinc addition to broiler diets on the immune response and production performance through a meta-analysis using data from published journal articles.

\section{MATERIALS AND METHODS}

\section{Development of the database}

A database was constructed based on data from published articles that reported the addition of various doses or forms of zinc to broiler diets and their effect on the immune response. Journal articles were searched using the tools Scopus, Science Direct, and Google Scholar and the keywords "zinc", "broiler" and/or "immune". If the papers contained immune response and production performance, the data on production performance would be collected for analysis. However, if the papers only reported production performance without data on immune response, these papers would not be included in the analysis.

The parameters included in the database were weight of the lymphoid organs, zinc concentration in tissue, average daily gain (ADG), feed intake, FCR, mortality, minerals on tibia, blood parameters, haematology, metallothionein (MT), antioxidant activity, immunoglobulin parameters (IgA, IgG, IgM) and complement parameters $(\mathrm{C} 3, \mathrm{C} 4)$. After searching using the keywords above, 60 articles were found. The next stage was an abstract evaluation, which resulted in 50 articles that could potentially be used. The next process was an evaluation of the entire article, which resulted in 41 articles that could be used. Finally, the data from 41 journal articles were entered into the database (Table 1). Abstract and full article evaluations were carried out by determining whether zinc was added to the diet and whether immunity or production parameters were examined.

As indicated in Table 1, several forms of zinc were applied, such as organic, inorganic and control (no addition). The added doses ranged from 0 (control) to $200 \mathrm{mg} / \mathrm{kg}$ of diet. The added zinc dose did not include zinc derived from feedstuffs. In the process of tabulating data into a database, the data for similar variables were converted to the same measurement units, which facilitated further analysis processing.

\section{Analysis of data}

The data included in the database had compatible measurement units and were further processed in a statistical meta-analysis based on a mixed model methodology $[52,53]$. Different studies were grouped as random effects, and the dose or different forms of zinc were grouped as fixed effects. The present meta-analysis used two types of statistical models to determine whether the predictor variables were continuous or discrete. The statistical model used in this study was based on p-values. The criterion for determining the significance of the effect for each variable was a p-value $<0.05$. When the p-value was between 0.05 and 0.1 , the effect had a tendency to be significant. All statistical analyses were carried out using SAS software version 9.1 [54].

\section{RESULTS}

The effect of dose or different forms of zinc on broiler immune response are shown in Table 2 and 3, respectively. Generally, the dose or zinc form did not have any significant effect on the weight of lymphoid organs (i.e., thymus, bursa of fabricius, spleen) or hematology parameters (i.e., hemoglobin, hematocrit). The zinc dose decreased liver weight by following a quadratic pattern $(\mathrm{p}<0.05)$. The zinc dose that gave the lowest liver weight was $107 \mathrm{mg} / \mathrm{kg}$. Increasing zinc dose significantly reduced the heterophil/lymphocyte $(\mathrm{H} / \mathrm{L})$ ratio with a quadratic pattern $(p<0.05)$, and both organic and inorganic zinc were effective in reducing the $\mathrm{H} / \mathrm{L}$ ratio $(\mathrm{p}<0.05)$. The dose of zinc that gave the lowest of $\mathrm{H} / \mathrm{L}$ ratio was $106 \mathrm{mg} / \mathrm{kg}$. Furthermore, the zinc dose and inorganic form increased the pancreas MT $(\mathrm{p}<0.05)$. The zinc dose did not affect antioxidant activity (superoxide dismutase [SOD]) in the meat and liver tissues. Furthermore, zinc dose tended to reduce malonaldehyde (MDA) concentrations in the liver $(\mathrm{p}<0.10)$. Different zinc forms increased the antioxidant activity of SOD in meat $(\mathrm{p}<0.05)$. Organic zinc resulted in the highest SOD activity in meat. In contrast, the SOD activity and MDA concentrations in the liver were not significantly influenced by different zinc forms. Immunoglobulin parameters (IgA, IgG, IgM) and complement parameters $(\mathrm{C} 3, \mathrm{C} 4)$ were not significantly affect- 
Table 1. Studies included in the meta-analysis of zinc addition on immune response and performance of broiler

\begin{tabular}{|c|c|c|c|c|}
\hline No & References & Period (d) & Form of zinc & Dose $(\mathrm{mg} / \mathrm{kg})$ \\
\hline 1 & Dozier et al [13] & $0-17$ & Zinc sulphate; Availa zinc (organic) & $40-120$ \\
\hline 2 & Ao et al [14] & $0-42$ & Zinc sulphate; Bioplex zinc (Zinc proteinate) & $0-40$ \\
\hline 3 & Aoyagi and Baker [15] & $8-22$ & Zinc sulphate; Zinc lysine & $0-8$ \\
\hline 4 & Bartlett and Smith [16] & $0-49$ & Zinc polyamino acid complex & $34-181$ \\
\hline 5 & Bafundo et al [17] & $8-22$ & Zinc monocarbonate; & $0-52$ \\
\hline 6 & Cao et al [6618] & $0-6$ & Zinc acetate; Zinc proteinate, Zinc methionine & $0-90$ \\
\hline 7 & Chan et al [4] & $0-35$ & Zinc inorganic (ND) & $0-60$ \\
\hline 8 & Aksu et al [19] & $0-42$ & Zinc sulphate & $13-40$ \\
\hline 9 & Feng et al [20] & $0-42$ & Zinc glycine; Zinc sulphate & $0-120$ \\
\hline 10 & Huang et al [21] & $0-21$ & Zinc sulphate & $0-140$ \\
\hline 11 & Dibaiee-nia et al [22] & $0-21$ & Zinc oxide & $0-100$ \\
\hline 12 & Rao et al [23] & $0-21$ & Bioplex zinc (Zinc proteinate) & $0-40$ \\
\hline 13 & Stahl et al [24] & $0-21$ & Zinc carbonate & $37-119$ \\
\hline 14 & Sunder et al [25] & $0-28$ & Zinc sulphate & $0-160$ \\
\hline 15 & Vieira et al [26] & $0-41$ & Zinc sulphate; Zinc methionine & $0-100$ \\
\hline 16 & Jarosz et al [27] & $0-42$ & Zinc sulphate; Zinc glycinate & 100 \\
\hline 17 & Hudson et al [28] & $0-17$ & Zinc sulphate; Zinc amino acid complex & 160 \\
\hline 18 & Kwiecien et al [29] & $0-42$ & Zinc oxide; Zinc glycinate & $0-100$ \\
\hline 19 & Li et al [30] & $3-14$ & Zinc sulphate; Zinc tribasic sulphate & $0-90$ \\
\hline 20 & Yan et al [31] & $0-42$ & Zinc sulphate & $0-80$ \\
\hline 21 & Kakhki et al [32] & $0-35$ & Zinc methionine & $0-120$ \\
\hline 22 & Azad et al [33] & $0-28$ & Zinc sulphate; Zinc methionine; Zinc-enriched yeast & $0-80$ \\
\hline 23 & Liao et al [34] & $22-42$ & Zinc sulphate & $0-140$ \\
\hline 24 & Moghaddam and Jahanian [35] & $0-42$ & Zinc sulphate; Zinc methionine; Zinc oxide & 40 \\
\hline 25 & Sahoo et al [36] & $0-42$ & Zinc sulphate; Zinc methionine & $0-15$ \\
\hline 26 & Chitithoti et al [37] & $0-42$ & Zinc sulphate; Zinc methionine & $0-80$ \\
\hline 27 & Donmez et al [38] & $0-45$ & Zinc sulphate & $0-125$ \\
\hline 28 & Roy et al [39] & $0-35$ & Zinc sulphate & $0-15$ \\
\hline 29 & Sunder et al [40] & $0-35$ & Commercial organic zinc (ND) & $4-160$ \\
\hline 30 & Ma et al [41] & $0-21$ & Zinc glycinate & $0-120$ \\
\hline 31 & Mohanna and Nys [42] & $5-21$ & Zinc sulphate; Zinc methionine & $0-40$ \\
\hline 32 & Pimentel et al [43] & $0-28$ & Zinc oxide & $8-88$ \\
\hline 33 & Yang et al [44] & $0-42$ & Inorganic zinc (as conventional inorganic sulphate salts) & $0-120$ \\
\hline 34 & Badawi et al [45] & $0-42$ & Zinc sulphate ; Zinc methionine & $0-40$ \\
\hline 35 & Sajadifar [46] & $0-42$ & Zinc sulphate & $40-200$ \\
\hline 36 & Yogesh et al [47] & $0-42$ & Zinc sulphate; Zinc oxide; Zinc propionate & $40-100$ \\
\hline 37 & Kulkarni et al [6] & $0-42$ & Zinc oxide & $0-120$ \\
\hline 38 & Ibrahim et al [48] & $0-42$ & Zinc oxide; Zinc methionine & $0-50$ \\
\hline 39 & Lai et al [49] & $0-42$ & Zinc oxide & $0-60$ \\
\hline 40 & Ivanisinova et al [50] & $0-35$ & Zinc sulphate; Zinc-glycine, Zinc propionate & 120 \\
\hline 41 & Ezzati et al [51] & $0-42$ & Zinc sulphate & $0-75$ \\
\hline
\end{tabular}

ed by the dose or different zinc form.

The effect of dose or form of zinc on broiler production performance is shown in Table 4 and Table 5, respectively. The production performance of broilers, i.e., $\mathrm{ADG}$ and FCR was significantly improved by increasing dose of zinc ( $\mathrm{p}<0.05$; Table 4). As the effect was in quadratic response, the optimum dose of zinc that gave the highest ADG and the lowest FCR were 93.37 and $75.72 \mathrm{mg} / \mathrm{kg}$, respectively. Meanwhile, average daily intake, mortality, carcass percentage, and abdominal fat percentage were not significantly affected by increased zinc dose or different zinc forms. Different zinc forms decreased FCR $(\mathrm{p}<0.05)$, although differences were not observed among the two forms. In addition, abdominal fat percentage of broilers reduced compared to that of control group but only inorganic zinc that significantly reduced $(\mathrm{p}<0.05)$. No difference was found on abdominal fat percentage between any form of zinc. Zinc concentrations in plasma, tibia and meat increased under increased zinc dose $(\mathrm{p}<0.05)$. The blood parameters (total protein and albumin) were not significantly influenced by the dose or form of zinc. Different zinc forms increased zinc 
Table 2. Regression equations on the influence of zinc doses (in $\mathrm{mg} / \mathrm{kg}$ of diet) on immune response of broilers

\begin{tabular}{|c|c|c|c|c|c|c|c|c|c|}
\hline \multirow{2}{*}{ Response parameter } & \multirow{2}{*}{ Unit } & \multirow{2}{*}{ Model } & \multirow{2}{*}{$\mathrm{N}$} & \multicolumn{4}{|c|}{ Parameter estimates } & \multicolumn{2}{|c|}{ Model estimates } \\
\hline & & & & Intercept & SE intercept & Slope & SE slope & p-value & $\mathrm{AIC}^{1)}$ \\
\hline \multicolumn{10}{|l|}{ Lymphoid organ weight } \\
\hline Thymus & $\%$ BW & $\mathrm{L}$ & 43 & 0.31 & 0.032 & 0.00026 & 0.00019 & 0.172 & -81.8 \\
\hline Bursa fabricious & $\%$ BW & $\mathrm{L}$ & 49 & 0.25 & 0.054 & 0.00013 & 0.00015 & 0.38 & -87.7 \\
\hline Spleen & $\%$ BW & $L$ & 64 & 0.22 & 0.091 & -0.00004 & 0.00015 & 0.81 & -114 \\
\hline \multirow[t]{2}{*}{ Liver } & $\%$ BW & Q & 27 & 2.14 & 0.265 & -0.00472 & 0.001799 & 0.016 & - \\
\hline & & & & & & 0.000022 & $9.013 \mathrm{E}-6$ & 0.0254 & 27.5 \\
\hline \multicolumn{10}{|l|}{ Haematologys } \\
\hline Haemoglobin & $\mathrm{g} / \mathrm{dL}$ & $\mathrm{L}$ & 10 & 8.11 & 0.76 & -0.00058 & 0.0035 & 0.872 & 27.1 \\
\hline Hematocryt & $\%$ & $L$ & 10 & 28.3 & 1.31 & -0.017 & 0.008 & 0.083 & 41.1 \\
\hline \multirow[t]{2}{*}{ H/L ratio } & $\% / \%$ & Q & 18 & 0.585 & 0.0641 & -0.00383 & 0.000851 & 0.0006 & - \\
\hline & & & & & & 0.000018 & $5.63 \mathrm{E}-6$ & 0.0075 & -8.7 \\
\hline \multicolumn{10}{|l|}{ Metallothionein } \\
\hline \multirow[t]{2}{*}{ Pancreas MT } & $\mathrm{RQ}$ & Q & 26 & 36 & 3.68 & 0.629 & 0.0765 & $<0.0001$ & - \\
\hline & & & & & & -0.00347 & 0.000611 & $<0.0001$ & 173 \\
\hline \multicolumn{10}{|l|}{ Antioxidant activity } \\
\hline SOD on meat & $\mathrm{U} / \mathrm{mg}$ protein & $\mathrm{L}$ & 10 & 53.5 & 2.84 & 0.043 & 0.053 & 0.444 & 60.7 \\
\hline SOD on liver & $\mathrm{U} / \mathrm{mg}$ protein & $\mathrm{L}$ & 21 & 161 & 21.9 & 0.23 & 0.17 & 0.198 & 211 \\
\hline MDA on liver & $\mathrm{nmol} / \mathrm{mL}$ & L & 15 & 4.31 & 0.670 & -0.0055 & 0.003 & 0.097 & 39.5 \\
\hline \multicolumn{10}{|c|}{ Immunoglobulin (Ig) and complement (C) } \\
\hline $\lg A$ & $g / L$ & L & 12 & 0.0406 & 0.014 & 0.000048 & 0.000177 & 0.792 & -29 \\
\hline $\lg G$ & $g / L$ & $\mathrm{~L}$ & 12 & 0.0484 & 0.010 & 0.000054 & 0.000124 & 0.671 & -36.1 \\
\hline $\lg M$ & $g / L$ & $\mathrm{~L}$ & 12 & 0.0442 & 0.011 & 0.000111 & 0.000137 & 0.437 & -34.0 \\
\hline $\mathrm{C} 3$ & $\mathrm{~g} / \mathrm{L}$ & $\mathrm{L}$ & 12 & 0.0372 & 0.009 & 0.000107 & 0.000115 & 0.371 & -37.6 \\
\hline C4 & $g / L$ & $\mathrm{~L}$ & 12 & 0.0284 & 0.010 & 0.000025 & 0.000125 & 0.848 & -35.9 \\
\hline
\end{tabular}

SE, standard error; AIC, akaike information criterion; BW, body weight; L, linear; Q, quadratic; H/L, heterophil/lymphocyte; MT, metallothionein; RQ, relative quantities of MT mRNA to $\beta$-actin mRNA in which RQ calculated by using this formula $2-\Delta \Delta \mathrm{Ct}(\mathrm{Ct}=$ threshold cycle); SOD, superoxide dismutase; MDA, malonaldehyde.

1) $\mathrm{AIC}$ is an estimator of the relative quality of statistical models for a given set of data.

concentration in the plasma and tibia $(\mathrm{p}<0.05)$, with organic and inorganic zinc producing similar concentrations. The optimum dose of zinc addition in broiler diet which resulted in the best zinc concentrations in the plasma, tibia and meat were $125,116.5,63.3 \mathrm{mg} / \mathrm{kg}$, respectively. The different zinc forms tended to increase zinc concentration in meat $(\mathrm{p}<0.1)$. Increasing zinc dose tended to increase calcium concentration in the tibia. In addition, an increase in zinc dose did not have any effect on the phosphorous content in tibia, while different zinc forms increased calcium and phosphorous contents in the tibia $(\mathrm{p}<0.05)$. Differences were not observed in the effects of organic and inorganic zinc on calcium content in the tibia. Organic zinc resulted in the highest phosphorous content in the tibia compared to inorganic form or control treatment.

\section{DISCUSSION}

Influence of zinc addition on the broiler immune response

The insignificant effects of zinc addition on thymus, bursa of fabricius and spleen could have been a direct result of the nonsignificant effect of the zinc on feed consumption (Tables 4,5 ); thus, the supply of nutrients for the development of these organs was not altered. Bartlett and Smith [16] explained that zinc addition to broiler diets did not affect the relative weight of lymphoid organs because zinc consumed by broilers was preferentially used to support the metabolic processes that support growth performance, whereas the use of zinc for the development of organs related to the immune system was minimized. Cui et al [55] stated that zinc has an important role in the broiler immune system, which can be seen from the limited development of either lymphoid organs or the mature population of blood T lymphocytes when zinc deficiency occurs in broilers. In chickens, zinc-deficient birds have characteristic microscopic lesions in their lymphoid organs [56]. Lymphoid organs are part of the structure and function of the immune system in broilers that can protect the body from attack by microorganisms, and zinc is known to have an important role in the immune system of the animal because it is needed in the function, structure, and development of the immune system [57]. Lymphoid tissue in broilers is divided into two groups: the central lymphoid (thymus, bursa) and the peripheral lymphoid (spleen). The two lymphoid tis- 
Table 3. Influence of zinc forms on immune response of broilers

\begin{tabular}{|c|c|c|c|c|c|c|}
\hline \multirow{2}{*}{ Response parameter } & \multirow{2}{*}{ Unit } & \multirow{2}{*}{$N$} & \multicolumn{3}{|c|}{ Zinc form } & \multirow{2}{*}{$\mathrm{p}$-value } \\
\hline & & & Control & Organic & Inorganic & \\
\hline Dose average & $\mathrm{mg} / \mathrm{kg}$ & & 0 & 62.83 & 62.89 & \\
\hline \multicolumn{7}{|l|}{ Lymphoid organ weight } \\
\hline Thymus weight & $\% \mathrm{BW}$ & 43 & 0.284 & 0.333 & 0.332 & 0.227 \\
\hline Bursa fabricious weight & $\%$ BW & 49 & 0.228 & 0.263 & 0.272 & 0.248 \\
\hline Spleen weight & $\% \mathrm{BW}$ & 64 & 0.198 & 0.229 & 0.229 & 0.386 \\
\hline Liver weight & $\%$ BW & 27 & $2.17^{\mathrm{a}}$ & $2.00^{\mathrm{ab}}$ & $1.90^{b}$ & 0.094 \\
\hline \multicolumn{7}{|l|}{ Haematology } \\
\hline Haemoglobin & $\mathrm{g} / \mathrm{dL}$ & 10 & 8.13 & nd & 8.05 & 0.756 \\
\hline Hematocryt & $\%$ & 10 & 27.9 & nd & 27.1 & 0.250 \\
\hline $\mathrm{H} / \mathrm{L}$ ratio & $\% / \%$ & 18 & $0.60^{b}$ & $0.43^{\mathrm{a}}$ & $0.46^{\mathrm{a}}$ & 0.016 \\
\hline \multicolumn{7}{|l|}{ Metallothionein } \\
\hline Pancreas MT & $\mathrm{RQ}$ & 14 & $1.00^{\mathrm{a}}$ & nd & $2.08^{b}$ & 0.002 \\
\hline \multicolumn{7}{|l|}{ Antioxidant activity } \\
\hline SOD on meat & U/mg protein & 10 & $46.5^{a}$ & $58.1^{b}$ & $52.9^{\mathrm{ab}}$ & 0.009 \\
\hline SOD on liver & U/mg protein & 21 & 158 & 197 & 176 & 0.312 \\
\hline MDA on liver & $\mathrm{nmol} / \mathrm{mL}$ & 15 & 4.28 & 3.86 & 4.01 & 0.546 \\
\hline \multicolumn{7}{|c|}{ Immunoglobulin (Ig) and complement (C) } \\
\hline $\lg \mathrm{A}$ & $g / L$ & 12 & 0.040 & 0.044 & 0.044 & 0.977 \\
\hline $\lg G$ & $g / L$ & 12 & 0.045 & 0.054 & 0.051 & 0.861 \\
\hline $\lg M$ & $g / L$ & 12 & 0.041 & 0.054 & 0.054 & 0.776 \\
\hline $\mathrm{C} 3$ & $g / L$ & 12 & 0.035 & 0.046 & 0.049 & 0.714 \\
\hline C4 & $g / L$ & 12 & 0.028 & 0.031 & 0.029 & 0.975 \\
\hline
\end{tabular}

BW, body weight; nd, no available data; H/L, heterophi/lymphocyte; MT, Metallothionein; RQ, relative quantities of MT mRNA to $\beta$-actin mRNA in which RQ calculated by using this formula $2-\Delta \Delta \mathrm{Ct}(\mathrm{Ct}=$ threshold cycle); SOD, superoxide dismutase; MDA, malonaldehyde.

a,b Different superscripts within the same row are significantly different at $p<0.05$.

sues are associated with the intestinal mucosa [58]. The bursa of fabricius is the main lymphoid organ in poultry that has an important function in B lymphocyte differentiation [59]. Tanaka et al [60] reported that zinc is required for lymphocyte proliferation. During organ development, the bursa of fabricius in the body of birds reaches its maximum size at the age of 8 to 10 weeks [61]. Kidd et al [57] revealed that the level of zinc addition in the diet of poultry affected the size of the lymphoid organs, which is related to the function of $\mathrm{T}$ cells and decreased when the diet was added with low amounts of zinc. The factor that reduced lymphoid organ weight was heat stress in the environment [62]. Studies by Jeurissen [63] or Smith and Hunt [64] reported that the function of the spleen is to support the development of lymphocytes, which have a crucial function in cellular and humoral immunity. As stated by Moller and Erritzoe [65], the mass size of the spleen is closely related to the level of humoral immunity, and a large spleen size will result in high humoral immunity, and vice versa. Increasing zinc level reduced liver weight percentage compared to other lymphoid organs, because transfer of zinc to liver from plasma is 5 to 6 times faster than transfer to other major tissue [66]. Liver weight affected by dietary zinc alteration may be due to the critical role of liver on zinc metabolism [67].

Hematology parameters (i.e., hemoglobin and hemato- crit) were not significantly influenced by the zinc dose. This result indicated that zinc addition may not significantly alter blood constituents. The H/L ratio is an index of stress in birds [68]. The doses and different forms of zinc reduced the H/L ratio, and the various zinc forms, i.e., organic and inorganic, had a similar effect on the $\mathrm{H} / \mathrm{L}$ ratio. The dose of zinc that gave the lowest of H/L ratio was $106 \mathrm{mg} / \mathrm{kg}$. Studies have shown that increased zinc doses have a positive impact on suppressing stress in broilers. Kidd et al [57] showed that adequate zinc is needed to produce lymphocytes normally during development; therefore, zinc deficiency resulted in a reduction in the number of peripheral $\mathrm{T}$ cells, decreased $\mathrm{T}$ helper cell function and depleted thymocytes in the thymus. Zinc addition supported the optimum development of lymphocytes, which alleviated stress. An increase in the lymphocyte count and decrease in the $\mathrm{H} / \mathrm{L}$ ratio might be attributed to decreased glucocorticoid secretion [68]. Furthermore, Walsh et al [69] explained that zinc contributes to noncovalent reactions of cytoplasmic components by tyrosine kinase, which is an essential protein in the early stages of lymphocytes activity. Dardenne et al [70] revealed that zinc is a thymulin cofactor that binds with thymic hormone to surface receptors of $\mathrm{T}$ lymphocytes and leads to the maturation and activation of these cells. Zinc binds to thymulin by asparagine side chains and hydroxyl 
Table 4. Regression equations on the influence of zinc doses (in $\mathrm{mg} / \mathrm{kg}$ of diet) on production performance, zinc concentration in tissue and bone, deposition of calcium and phosphorous in tibia of broilers

\begin{tabular}{|c|c|c|c|c|c|c|c|c|c|}
\hline \multirow{2}{*}{ Response parameter } & \multirow{2}{*}{ Unit } & \multirow{2}{*}{ Model } & \multirow{2}{*}{$\mathrm{N}$} & \multicolumn{4}{|c|}{ Parameter estimates } & \multicolumn{2}{|c|}{ Model estimates } \\
\hline & & & & Intercept & SE intercept & Slope & SE slope & $p$-value & $\mathrm{AIC}^{1)}$ \\
\hline \multicolumn{10}{|l|}{ Production performance } \\
\hline \multirow[t]{2}{*}{ Average daily gain } & $\mathrm{g} / \mathrm{bird} / \mathrm{d}$ & Q & 195 & 39.5 & 3.48 & 0.0691 & 0.0260 & 0.008 & - \\
\hline & & & & & & -0.00037 & 0.000149 & 0.0131 & 1,355 \\
\hline \multirow[t]{2}{*}{ Feed conversion ratio } & $\mathrm{g}$ feed/g gain & Q & 154 & 1.75 & 0.0546 & -0.00083 & 0.000359 & 0.0223 & - \\
\hline & & & & & & $5.48 \mathrm{E}-6$ & $1.98 \mathrm{E}-6$ & 0.0060 & -225 \\
\hline Mortality & $\%$ & L & 12 & 0.30 & 0.962 & 0.0085 & 0.0085 & 0.344 & 51.6 \\
\hline Average daily intake & $\mathrm{g} / \mathrm{bird} / \mathrm{d}$ & $L$ & 174 & 71.1 & 6.66 & 0.018 & 0.014 & 0.21 & 1,310 \\
\hline Carcass percentage & $\%$ & L & 14 & 68.7 & 2.66 & 0.0073 & 0.0120 & 0.552 & 69.1 \\
\hline Abdominal fat & $\%$ & $\mathrm{~L}$ & 11 & 1.01 & 0.219 & -0.0027 & 0.00179 & 0.166 & 16.4 \\
\hline \multicolumn{10}{|l|}{ Zinc concentration } \\
\hline \multirow[t]{2}{*}{ Plasma } & $\mu \mathrm{g} / \mathrm{mL}$ & Q & 76 & 1.35 & 0.215 & 0.010 & 0.00166 & $<0.0001$ & - \\
\hline & & & & & & -0.00004 & $8.56 \mathrm{E}-6$ & $<0.0001$ & 58.9 \\
\hline \multirow[t]{2}{*}{ Tibia } & $\mathrm{mg} / \mathrm{kg}$ ash basis & Q & 96 & 248 & 26.6 & 2.82 & 0.387 & $<0.0001$ & - \\
\hline & & & & & & -0.0121 & 0.00227 & $<0.0001$ & 1,091 \\
\hline Liver & $\mu \mathrm{g} / \mathrm{g}$ dry matter & $L$ & 27 & 2.01 & 0.25 & -0.00056 & 0.00057 & 0.339 & 11.4 \\
\hline \multirow[t]{2}{*}{ Meat } & $\mu \mathrm{g} / \mathrm{g}$ & Q & 20 & 24.3 & 3.15 & 0.157 & 0.051 & 0.0083 & - \\
\hline & & & & & & -0.00124 & 0.000482 & 0.0219 & 113 \\
\hline \multicolumn{10}{|l|}{ Minerals on Tibia } \\
\hline Calcium & $\%$ & L & 21 & 32.1 & 4.42 & 0.018 & 0.010 & 0.08 & 115 \\
\hline Phosphorous & $\%$ & L & 18 & 15.3 & 0.99 & 0.0031 & 0.0044 & 0.496 & 64.1 \\
\hline \multicolumn{10}{|l|}{ Blood parameters } \\
\hline Total of protein & $g / L$ & L & 12 & 28.6 & 1.46 & 0.023 & 0.017 & 0.215 & 62.9 \\
\hline Albumin & $g / L$ & $L$ & 12 & 13.7 & 1.03 & 0.004 & 0.012 & 0.756 & 56.1 \\
\hline
\end{tabular}

$\mathrm{SE}$, standard error; AIC, akaike information criterion; Q, quadratic; L, linear.

1) $\mathrm{AIC}$ is an estimator of the relative quality of statistical models for a given set of data (smaller is better).

Table 5. Influence of zinc forms on production performance, zinc concentration in tissue and bone, deposition of calcium and phosphorous in tibia of broilers

\begin{tabular}{|c|c|c|c|c|c|c|}
\hline \multirow{2}{*}{ Response parameter } & \multirow{2}{*}{ Unit } & \multirow{2}{*}{$\mathrm{N}$} & \multicolumn{3}{|c|}{ Zinc form } & \multirow{2}{*}{ p-value } \\
\hline & & & Control & Organic & Inorganic & \\
\hline Dose average & $\mathrm{mg} / \mathrm{kg}$ & & 0 & 62.83 & 62.89 & \\
\hline Average daily gain & $\mathrm{g} / \mathrm{bird} / \mathrm{d}$ & 195 & 39.2 & 42.2 & 41.4 & 0.222 \\
\hline Feed conversion ratio & $\mathrm{g}$ feed/g gain & 154 & $1.78^{b}$ & $1.72^{\mathrm{a}}$ & $1.73^{\mathrm{a}}$ & 0.017 \\
\hline Mortality & $\%$ & 12 & 0 & 1.28 & 1.30 & 0.707 \\
\hline Carcass & $\%$ & 14 & 68.1 & 69.4 & 69.5 & 0.448 \\
\hline Abdominal fat & $\%$ & 11 & $1.18^{\mathrm{a}}$ & $0.98^{\mathrm{ab}}$ & $0.68^{b}$ & 0.034 \\
\hline \multicolumn{7}{|l|}{ Zinc concentration } \\
\hline Plasma & $\mu \mathrm{g} / \mathrm{mL}$ & 76 & $1.31^{\mathrm{b}}$ & $1.65^{\mathrm{a}}$ & $1.88^{\mathrm{a}}$ & $<0.0001$ \\
\hline Tibia & $\mathrm{mg} / \mathrm{kg}$ ash basis & 96 & $230^{b}$ & $343^{\mathrm{a}}$ & $369^{a}$ & $<0.0001$ \\
\hline Phosphorous & $\%$ & 18 & $14.7^{\mathrm{a}}$ & $16.6^{c}$ & $15.2^{b}$ & $<0.0001$ \\
\hline \multicolumn{7}{|l|}{ Blood parameters } \\
\hline Serum total of protein & $g / L$ & 12 & 27.5 & 30.8 & 30.4 & 0.363 \\
\hline Albumin & $\mathrm{g} / \mathrm{L}$ & 12 & 13.4 & 14.3 & 13.8 & 0.857 \\
\hline
\end{tabular}

${ }^{a-c}$ Different superscripts within the same row are significantly different at $p<0.05$. 
groups. Therefore, the addition of zinc to the diet increased thymulin activity, which led to the more appropriate maturation and activity of $\mathrm{T}$ lymphocytes [71].

In addition, the dose and inorganic forms of zinc increased pancreas MT. Zinc has an important role in many physiological functions, which includes numerous metalloenzyme systems [72]. Andrews [73] stated that MT is a cysteine-rich protein that has the ability to bind zinc and other heavy metals involved in stress response activities. Researchers have also demonstrated that MT is synthesized in tissues in response to dietary zinc and binds excess zinc, which has a negative impact on the body $[21,74]$. Moreover, other researchers, i.e., Wedekind et al [75] and Sandoval et al [74], have reported that pancreas MT protein may represent a good indicator of the zinc status of chickens. The optimum dose that produces the highest pancreatic MT was $90.63 \mathrm{mg} / \mathrm{kg}$. Because the only available data were for the control and inorganic groups, the current study could compare only the effects of the inorganic zinc group and the control group.

The zinc dose did not affect antioxidant activity (i.e., SOD in meat and the liver). Zinc is a cofactor for SOD and has an important function in antioxidant systems, i.e., as an inhibitor of the oxidation process by protecting proteins and enzymes and as an inhibitor of the formation of free radicals [76-78]. SOD is widely distributed and protecting various organs and tissues from peroxidation [79]. Similarly, a study by Zago and Oteiza [80] showed that zinc is the main component of $\mathrm{Cu} /$ zinc SOD, and SOD has cell defense functions against oxidative stress, which explains why zinc deficiency can lead to the increased production of free radicals [81].

The MDA in the liver tended to decrease as the zinc dose increased, which indicated that an increasing zinc dose tended to inhibit lipid peroxidation (LPO). Tupe et al [82] revealed that the dietary zinc status exerted a powerful influence on the degree of oxidative damage caused by free radicals. MDA is a product of the process of lipid oxidation. Higher MDA values correlate with higher oxidized lipid values. Lipid oxidation is related to antioxidant activity. The role of zinc, which is important in antioxidant activity, is expected to have an impact on the reduction of the lipid oxidation process $[80,83]$. Concentrations of MDA in the liver were not significantly influenced by the different zinc forms. MDA is an indicator of the occurrence of LPO; hence, MDA can reflect the hepatocyte membrane damage level and LPO in the liver. Prasad and Kucuk [84] explained that as a cofactor of many anti oxidative enzymes, zinc plays a key role in decreasing the production of free radicals. However, Raharjo and Sofos [85] explained that MDA is also widely used as an indicator of the amount of lipid oxidation in meat. In the current study, although not significantly different, the MDA levels in the liver following organic zinc addition were lower than those in the control. These results showed that zinc has the ability to inhibit LPO.
Previously, some researchers, i.e., Powell [86] and Prasad and Kucuk [84], reported that zinc reduces MDA, which indicates that zinc functions as an antioxidant agent because zinc reduces LPO in the cell membrane.

Different zinc forms increased the antioxidant activity of SOD in meat. The addition of organic zinc resulted in the highest SOD activity in meat. Zinc can improve this aspect of immunity because zinc is an important part of the process of cell integration, which is involved in the immune response [70]. The important role of zinc in the activity of the immune response is related to the impact of zinc on the antioxidant defense mechanisms in the body [84]. Tate et al [87] stated that zinc increases antioxidant activity by decreasing the production of free radicals because zinc competes with other minerals, such as copper and iron, in binding to cell membranes. Yamaguchy [88] and Gibbs et al [89] reported that $\mathrm{Cu} /$ zinc SOD has an important function in reducing free radical production.

The immunoglobulin parameters (IgA, IgG, and IgM) and complement parameters ( $\mathrm{C} 3$ and $\mathrm{C} 4$ ) were not significantly affected by the dose or different forms of zinc. Immunoglobulin is a protein that has antibody activity. These results were inconsistent with previous reports by Beach et al [90] and Burns [56], who showed that adding zinc to the zinc deficient diet increased the production of poultry antibodies. Furthermore, Feng et al [20] reported an improvement in immunoglobulin levels (IgA, IgM, and IgG) with the dietary replacement of $120 \mathrm{mg} / \mathrm{kg}$ of inorganic zinc $\left(\mathrm{ZnSO}_{4}\right)$ with 90 or $120 \mathrm{mg} / \mathrm{kg}$ of organic zinc (zinc-glycinate).

In the current study, zinc had a positive impact on reducing stress levels in broilers. This observation is evidenced by the ability of zinc to reduce the $\mathrm{H} / \mathrm{L}$ ratio and increase the pancreas MT. Zinc also tends to reduce MDA levels in the liver, which shows that zinc tends to suppress the occurrence of LPO. Zinc addition did not significantly affect the other immunity variables observed in this study due to variations in the experimental material used, especially changes related to the time or age at sampling and differences in environmental conditions. Accordingly, this study can be used as a reference for broiler farmers, that the addition of zinc in broiler diet can give benefit to improve their broiler health, through increasing broiler immunity. The optimum dose that produces the best pancreatic MT and reduced stress indicated by $\mathrm{H} / \mathrm{L}$ ratio were $90.63 \mathrm{mg} / \mathrm{kg}$ and $106 \mathrm{mg} / \mathrm{kg}$, respectively, which will perform the best broiler immunity.

\section{Influence of zinc addition on broiler production performance}

The production performance of broilers parameters, i.e., $\mathrm{ADG}$ and FCR was significantly improved by increases in the zinc dose (Table 4). This result supported the study before that zinc is the main trace mineral involved in the metabolism of car- 
bohydrates, lipids, and proteins [9]. Zinc has function as an enzyme cofactor that helps in the metabolism of nutrients so that they can be used more efficiently. Different zinc forms decreased the FCR, although the various forms did not show differences in their results. The optimum dose of zinc addition in broiler diet which resulted in the best ADG and FCR were 93.37 and $75.72 \mathrm{mg} / \mathrm{kg}$, respectively. The other production performances of broiler, i.e., average daily intake, mortality, and carcass percentage, were not significantly affected by increasing zinc dose or the different forms of zinc (Tables 4, 5). This study in line with several studies which reported that zinc addition on broiler diet had no effect on average daily intake, mortality and carcass percentage [91-93]. In contrast, several studies reported that zinc addition on broiler diet affected average daily intake, mortality and carcass percentage [51,94-96]. The difference in the effect of zinc addition to the diet on broiler production performance is allegedly also caused by differences in the breed of broiler, growth phase, and the presence of ligands in the diet that are able to bind zinc, i.e., phytate, thereby disrupting the absorption of zinc in the body because zinc is bound to and forms complex bonds [97]. The phytate will form complex bonds with minerals which have valences two, i.e., such as $\mathrm{Zn}, \mathrm{Mn}$, Ca, etc., which make those mineral undigested in the poultry's intestine [98]. Phytase supplementation will help release minerals bound with phytate so that can be absorbed by the poultry's intestine $[99,100]$.

Another positive effect of the addition of different zinc forms to broiler diets was reduced abdominal fat percentage. Inorganic zinc reduced the abdominal fat percentage of broilers compared to that of the control group. No difference was found on abdominal fat percentage between any form of zinc. In the current study, dietary inorganic zinc reduced the abdominal fat percentage of broiler rather than organic zinc, that is because, firstly, organic zinc sources that analyzed in this study were not the same organic compound (i.e., zinc proteinate, zinc lysine, zinc poly amino acid complex, zinc methionine, zinc glycine, zinc-enriched yeast, zinc propionate, zinc glycinate), that variation may contribute to the insignificant fat reduction effect. In terms of inorganic form, mostly zinc source was coming from zinc sulfate. Secondly. the bioavailability of inorganic zinc in monogastric is much lower [101]. This is because in the monogastric gastrointestinal tract, the inorganic zinc combined with phytic acid. Meanwhile, organic zinc which combined with amino-acids did not interact with phytic acid as they are lacking the free divalent cations needed for chelation in the intestine [57,102]. Higher bioavailability of organic zinc leads to higher fat metabolism in the liver, furthermore increasing the lipid synthesis for broilers through controlling the activities and gene expressions of lipogenic enzymes [103,104].

Ferrini et al [105] stated that efforts to reduce fat deposition in the chicken body has become one of the main topics of broiler research. This development is because consumers want poultry products that are high quality and meet high health criteria. The high fat content in animal products is known to be an underlying cause of obesity and coronary heart disease [106]. Reducing abdominal fat in broilers is not only a method of reducing the cost of production but also for improving the efficiency of the feed use because abdominal fat is considered waste. In the other words, the addition of organic zinc in broiler diets helps improve the quality of carcasses by decreasing the percentage of abdominal fat.

The zinc concentrations in the plasma and tibia increased with the dose and form of zinc. Organic and inorganic zinc addition produced similar concentrations. An increasing zinc dose and the addition of organic or inorganic zinc increased the zinc concentrations in the plasma and the tibia. The zinc concentrations in the plasma can be used as an indicator of the amount of zinc digested by the body of poultry in certain periods $[107,108]$. Therefore, the zinc concentrations in plasma are the most widely used indicator of zinc status because low values are considered an early symptom of zinc deficiency [12]. The optimum dose of zinc addition in broiler diet which resulted in the best zinc concentrations in the plasma, tibia and meat were $125,116.5$, and $63.3 \mathrm{mg} / \mathrm{kg}$, respectively. Bone is a mineral storage site, and zinc from the bone can be used by the body when there is a zinc deficiency [16]. The zinc content in bone is an appropriate indicator of zinc bioavailability in poultry diets [18]. The relationship between the zinc dose and zinc concentration in the plasma, tibia and liver followed a quadratic linear pattern with a positive slope for all variables, indicating the bioavailability of zinc [109]. Grynpas et al [110] stated that another reason why the levels of zinc in bone are an indicator of the bioavailability of zinc is because bone is a large storage area for zinc. For example, the zinc content in bone can reach $300 \mathrm{mg} / \mathrm{g}$; thus, zinc is an important element in bone metabolism. Accordingly, an adequate zinc concentration is required for the growth, development and mineralization of bone [84]. Bones become a zinc reserve in the body, and when a zinc deficiency occurs, the zinc in the bones will be used. The metabolism of zinc from bone is very dynamic, and zinc is distributed from the bone to other tissues when the body is deficient in zinc [74,107]. Furthermore, Attia et al [111] stated that zinc concentrations increase in the tibia due to the increased consumption of zinc-supplemented diets and higher subsequent delivery of both supplemental and basal zinc. Moreover, previous studies have demonstrated that the zinc content of the tibia is significantly influenced by dietary concentrations, and Loveridge [112] revealed that the highest zinc concentration in the tibia resulted from addition levels similar to those that resulted in birds attaining an optimal body weight. The mineral content in tissue is often used as an indicator of the mineral status of animals as well as the level of minerals consumed by animals 
[113]. In the current study, the average dose of organic zinc was $62.83 \mathrm{mg} / \mathrm{kg}$, while that for inorganic zinc was $62.89 \mathrm{mg} / \mathrm{kg}$ (Tables 3, 5). In this study, the average dose for organic and inorganic zinc is almost similar, which generally has a similar effect on the immune response and production performance of broiler. Comparing the current price of organic and inorganic zinc. Generally, the price of inorganic zinc cheaper than organic zinc, for example, the price of zinc-methionine for feed (organic zinc) is 5980-6120 USD/metric ton [114], while the price of zinc sulfate for feed (inorganic zinc) is $900-$ 1,100 USD/Metric ton [115]. Accordingly, using inorganic zinc, economically more efficient than organic zinc.

Generally, the effect of the different form of zinc does not have much effect on the parameters of production performance. This study differs from the several reports which stated that organic zinc will be better at giving effect to broiler production because it has better bioavailability. As reported by Berger et al [116] and Salim et al [117] who showed that the bioavailability of organic zinc was shown to be higher than that of inorganic zinc such that the amount of organic zinc used in the diet is less than that of inorganic zinc. The bioavailability of zinc greatly determines how many doses of zinc is used in the broiler diet, the higher bioavailability of zinc, the lower the dose of zinc used in the diet. The dose of zinc used in the broiler diet must be in accordance with the zinc requirement of a broiler because excessive use of zinc will cause zinc not to be used by the broiler body, thereby released through manure [118], which caused environmental pollution. The study by Zhang et al [119] showed that animal manure is an important source of heavy metals to the environment. The study by Giordano et al [120] reported that high concentrations of zinc on water and soil reduced crop yields. It is because zinc increased the acidity of waters so that zinc can interrupt the activity in soils, as it negatively influences the activity of microorganisms and earthworms, thus retarding the breakdown of organic matter. In the future, to suppress environmental pollution from zinc excreted through manure, zinc has been developed in the form of nanoparticles. The development of zinc nanoparticles are intended to reduce the dose of zinc used in the diet, hence, the lower dose of zinc added to the diet, accordingly, will be even less of zinc that excreted through manure. Feng et al [121] stated that zinc nanoparticles are more effective than the larger size of zinc at lower doses.

Increasing the zinc dose tended to increase the calcium concentration in the tibia. The quality of tibias was affected by element supplementation in the diet [94]. These results are consistent with those of Rayani et al [122], who stated that an increase in the zinc dose from 40 to $80 \mathrm{mg} / \mathrm{kg}$ significantly increased the calcium content of the tibia bone, with the highest calcium levels of $51.97 \%$ found when the experimental broiler chickens were added with $80 \mathrm{mg} / \mathrm{kg}$ of zinc.
Zinc addition at a dose of $80 \mathrm{mg} / \mathrm{kg}$ increased the calcium content by up to $37.41 \%$ [25]. In addition, increasing the zinc dose had no effect on the phosphorus contents in the tibia. The current study differs from that of Sunder et al [25] and Vieira et al [26], who showed that zinc addition significantly affected the phosphorus contents of the tibia. Different zinc forms increased the calcium and phosphorous contents in the tibia, although the effects of organic and inorganic zinc on the calcium content in the tibia did not differ. Organic zinc induced the highest phosphorus content in the tibia, thus indicating that organic zinc was efficient at supporting calcium and phosphorus deposition in the tibia. This result suggested that organic zinc was efficient at supporting calcium and phosphorus deposition in the tibia, indicating that various zinc forms did not have an antagonistic effect on the deposition of calcium and phosphorus in the tibia. Wang et al [123] reported that lower zinc content in the diet led to a reduction in bone length, bone density and bone integrity, and calcium and phosphorus are the main components of bones. Similarly, Loveridge [112] stated that trace minerals are an important component in bone formation and development.

Blood parameters (total protein, albumin) were not significantly influenced by the dose or form of zinc. Similarly, zinc addition in broiler diets does not improve serum parameters, including the protein concentration $[124,125]$. In contrast, Feng et al [20] reported that adding a diet with zinc increased the serum total protein concentrations. Zinc is related to blood protein levels because it is related to the metabolic activity of nutrients in the body because zinc supports enzymatic and physiological processes in the body, including the process of nutrient digestion in the digestive tract. Moreover, blood protein levels are associated with the time needed to digest nutrients in the digestive tract, and zinc is associated with nutritional digestive activity $[116,126]$. Walker et al [127] stated that health status could be considered from various aspects, including the protein content. Plasma proteins include albumin, globulin and fibrinogen, and they are involved in maintaining osmotic pressure, providing an amino acid source for tissues, transporting nutrients to cells and waste products to secretory organs, and maintaining the acid-base balance (buffer). Albumin has the ability to bind various ligands and is responsible for $80 \%$ of the osmotic pressure. Maggini et al [10] stated that zinc plays an important role in protein and nucleic acid synthesis because it is an important part of the enzymes involved their synthesis. Although significant differences were not observed, the different zinc forms increased the values of total protein and albumin compared with those in the control group.

In the current study, the addition of zinc to broiler feed had a positive impact on broiler production performance and could increase the ADG and the efficiency of feed use, which was based on a decrease in the FCR. Zinc also improved the 
broiler carcass quality by reducing the percentage of abdominal fat. In this study, the addition of zinc did not have a negative impact on bone mineral deposition, indicating that the addition of zinc did not have an antagonistic effect on calcium and phosphorus minerals. Accordingly, the current study can be used as a reference for broiler farmers to improve their broiler performance. Thereby, hopely the broiler farmers can get more economic benefits addition. The optimum addition zinc dose to broiler diet which affected the best ADG and feeds conversion ratio were 93.37 and 75.72 $\mathrm{mg} / \mathrm{kg}$, respectively, which will result in the best broiler production performance.

\section{CONCLUSION}

This study discovers the positive impact of zinc addition on immunity and production performance of broilers through a comprehensive meta-analysis study. The optimum dose that produces the best pancreatic MT and reduced stress indicated by $\mathrm{H} / \mathrm{L}$ ratio were $90.63 \mathrm{mg} / \mathrm{kg}$ and $106 \mathrm{mg} / \mathrm{kg}$, respectively, which will perform the best broiler immunity. Meanwhile, the optimum addition zinc dose to broiler diet which affected the best ADG and FCR were 93.37 and $75.72 \mathrm{mg} / \mathrm{kg}$, respectively, which will result in the best broiler production performance. Since the use of antibiotics in feed has been banned in many countries, adding zinc to broiler feed can help to increase broiler immunity.

\section{CONFLICT OF INTEREST}

We certify that there is no conflict of interest with any financial organization regarding the material discussed in the manuscript.

\section{ACKNOWLEDGMENTS}

This work is part of the research that funded by Indonesian Agency for Agricultural Research and Development through DIPA BALITBANGTAN.

\section{REFERENCES}

1. Salim HM, Jo C, Lee BD. Zinc in broiler feeding and nutrition. Avian Biol Res 2008;1:5-18.

2. Stefanidou MC, Maravelias, Dona A. Zinc: a multipurpose trace element. Arch Toxicol 2006;80:1-9. https://doi.org/10. 1007/s00204-005-0009-5

3. Vinus, SN. Role of nanotechnology in poultry nutrition. Int J Pure App Biosci 2017;5:1237-45.

4. Chand N, Naz S, Khan A, Khan S, Khan RU. Performance traits and immune response of broiler chicks treated with zinc and ascorbic acid supplementation during cyclic heat stress.
Int J Biometeorol 2014;58:2153-7. https://doi.org/10.1007/ s00484-014-0815-7

5. National Research Council. Nutrient requirements of poultry. 9th ed. Washington, DC, USA: National Academy Press; 1994.

6. Kulkarni RC, Mandal AB, Bhanja SK, et al. Dietary zin supplementation on performance of coloured broilers during hothumid summer. JPST 2007;4(Suppl 1):7-11.

7. Jaiswal SK, Raza M, Uniyal S, et al. Heat stress and its relation with expression of heat shock proteins in poultry. Int J Sci Environ 2017;6:159-66.

8. Kucuk O, Sahin N, Sahin K. Supplemental zinc and vitamin A can alleviate negative effects of heat stress in broiler chickens. Biol Trace Elem Res 2003;94:225-35. https://doi.org/10.1385/ BTER:94:3:225

9. Sahin K, Kucuk O. Zinc supplementation alleviates heat stress in laying Japanese quail. J Nutr 2003;133:2808-11. https://doi. org/10.1093/jn/133.9.2808

10. Maggini S, Wintergerst ES, Beveridge S, et al. Selected vitamins and trace elements support immune function by strengthening epithelial barriers and cellular and humoral immune response. Br J Nutr 2007;98 (Suppl 1):S29-35. https://doi.org/10.1017/ S0007114507832971

11.Sajadifar S, Miranzedah H, Moazeni M. Effect of zinc on humoral and cell-mediated immunity of broilers vaccinated against coccidiosis. Iranian J Parasitol 2013;8:474-80.

12. Underwood EJ, Suttle NF. The mineral nutrition of livestock. USA: CABI Publishing; 2001.

13.Dozier WA, Davis AJ, Freeman ME, Ward TL. Early growth and environmental implications of dietary zinc and copper concentrations and sources of broiler chicks. Br Poult Sci 2003;44:726-31. https://doi.org/10.1080/0007166031000164 3714

14. Ao T, Pierce JL, Pescatore AJ, et al. Effects of feeding different concentration and forms of zinc on the performance and tissue mineral status of broiler chicks. Br Poult Sci 2011;52:466-71. https://doi.org/10.1080/00071668.2011.588198

15. Aoyagi S, Baker DH. Nutritional evaluation of copper-lysine and zinc-lysine complexes for chicks. Poult Sci 1993;72:16571. https://doi.org/10.3382/ps.0720165

16. Bartlett JR, Smith MO. Effects of different levels of zinc on the performance and immunocompetence of broilers under heat stress. Poult Sci 2003;82:1580-8. https://doi.org/10.1093/ps/82. 10.1580

17. Bafundo KW, Baker DH, Fitzgerald PR. Zinc utilization in the chick as influenced by dietary concentrations of calcium and phytate and by Eimeria acervulina infection. Poult Sci 1984;63:2430-7. https://doi.org/10.3382/ps.0632430

18. Cao J, Henry PR, Davis SR, et al. Relative bioavailability of organic zinc sources based on tissue zinc and metallothionein in chicks fed conventional dietary zinc concentrations. Anim Feed Sci Technol 2002;101:161-70. https://doi.org/10.1016/ S0377-8401(02)00051-2 
19. Aksu DS, Aksu T, Özsoy B, Erol B. The effects of replacing inorganic with a lower level of organically complexed minerals $(\mathrm{Cu}, \mathrm{Zn}$ and $\mathrm{Mn})$ in broiler diets on lipid peroxidation and antioxidant defense systems. Asian-Australas J Anim Sci 2010; 23:1066-72. https://doi.org/10.5713/ajas.2010.90534

20.Feng J, Ma WQ, Niu NH, Wu XM, Wang Y, Feng J. Effects of zinc glycine chelate on growth, hematological, and immunological characteristics in broilers. Biol Trace Elem Res 2010;133: 203-11. https://doi.org/10.1007/s12011-009-8431-9

21. Huang YL, Lu L, Luo XG, Liu B. An optimal dietary zinc level of broiler chicks fed a corn-soybean meal diet. Poult Sci 2007; 86:2582-9. https://doi.org/10.3382/ps.2007-00088

22.Dibaiee-nia G, Akbari MR, Karimi S. Effects of supplemental zinc in a wheat-based diet on performance, intestinal viscosity, immune system and lipid peroxidation of 21-day old broiler chickens. Poult Sci J 2017;5:7-15. https://doi.org/10.22069/ PSJ.2017.11072.1189

23. Rao SVR, Prakash B, Raju MVLN, Panda AK, Kumari RK, Reddy EP. Effect of supplementing organic forms of zinc, selenium and chromium on performance, anti-oxidant and immune responses in broiler chicken reared in tropical summer. Biol Trace Elem Res 2016;172:511-20. https://doi.org/10.1007/ s12011-015-0587-x

24.Stahl JL, Greger JL, Cook ME. Zinc, copper and iron utilisation by chicks fed various concentrations of zinc. Br Poult Sci 2015; 30:123-34. https://doi.org/10.1080/00071668908417131

25.Sunder GS, Panda AK, Gopinath NCS, et al. Effects of higher levels of zinc supplementation on performance, mineral availability, and immune competence in broiler chickens. J Appl Poult Res 2008;17:79-86. https://doi.org/10.3382/japr.200700029

26. Vieira MM, Ribeiro AML, Kessler AM, Moraes ML, Kunrath MA, Ledur VS. Different sources of dietary zinc for broilers submitted to immunological, nutritional, and environmental challenge. J Appl Poult Res 2013;22:855-61. https://doi.org/10. 3382/japr.2013-00753

27.Jarosz Ł, Marek A, Gradzeki Z, Kwiecień M, Kalinowski M. The effect of feed supplementation with zinc chelate and zinc sulphate on selected humoral and cell-mediated immune parameters and cytokine concentration in broiler chickens. Res Vet Sci 2017;112:59-65. https://doi.org/10.1016/j.rvsc.2016. 09.007

28. Hudson BP, Iii WAD, Wilson JL. Broiler live performance response to dietary zinc source and the influence of zinc supplementation in broiler breeder diets. Anim Feed Sci Technol 2005;118:329-35. https://doi.org/10.1016/j.anifeedsci.2004. 10.018

29. Kwiecień M, Winiarska-mieczan A, Milczarek A, Tomaszewska E, Matras J. Effects of zinc glycine chelate on growth performance, carcass characteristics, bone quality, and mineral content in bone of broiler chicken. Livest Sci 2016;191:43-50. https://doi.org/10.1016/j.livsci.2016.07.005
30.Li W, Ma X, Lu L, Zhang L, Luo X. Relative bioavailability of tribasic zinc sulfate for broilers fed a conventional corn-soybean meal diet. J Integr Agric 2015;14:2042-9. https://doi.org/10. 1016/S2095-3119(15)61033-4

31. Yan R, Zhang L, Yang X, Wen C, Zhou Y. Applied clay science bioavailability evaluation of zinc-bearing palygorskite as a zinc source for broiler chickens. Appl Clay Sci 2015;119:155-60. https://doi.org/10.1016/j.clay.2015.07.027

32.Kakhki RAM, Bakhshalinejad R, Hassanabadi A, Ferket P. Effects of dietary organic zinc and $\alpha$-tocopheryl acetate supplements on growth performance, meat quality, tissues minerals, and $\alpha$-tocopherol deposition in broiler chickens. Poult Sci 2017;96:1257-67. https://doi.org/10.3382/ps/pew386

33. Azad SK, Shariatmadari F, Torshizi MAK, Ahmadi H. Effect of zinc concentration and source on performance, tissue mineral status, activity of superoxide dismutase enzyme and lipid peroxidation of meat in broiler chickens. Anim Prod Sci 2017;58: 1837-46. https://doi.org/10.1071/AN15758

34.Liao X, Li A, Lu L, et al. Optimal dietary zinc levels of broiler chicks fed a corn-soybean meal diet from 22 to 42 days of age. Anim Prod Sci 2013;53:388-94. https://doi.org/10.1071/ AN12291

35. Moghaddam HN, Jahanian R. Immunological responses of broiler chicks can be modulated by dietary supplementation of zinc-methionine in place of inorganic zinc sources. AsianAustralas J Anim Sci 2009;22:396-403. https://doi.org/10.5713/ ajas.2009.80473

36. Sahoo A, Swain R, Mishra SK. Effect of inorganic, organic and nano zinc supplemented diets on bioavailability and immunity status of broilers introduction. Int J Adv Res 2014;2:828-37.

37. Chitithoti AK, Venkata RJ, Jwalapu RP, Devanesan SS, Reddy S. Immuno stimulatory effect of dietary supplementation of zinc sulphate and zinc-methionine on immune response in broilers. Adv Appl Sci Res 2012;3:2785-8.

38. Donmez N, Donmez HH, Keskin E, Celik I. Effects of zinc supplementation to ration on some hematological parameters in broiler chicks. Biol Trace Elem Res 2002;87:125-31. https:// doi.org/10.1385/BTER:87:1-3:125

39. Roy A, Mandal GP, Pal K, Samanta I, Biswas P, Roy B. Effect of zinc supplementation with or without phytase on performance, mineral accumulation in tissues and immune response of broiler. Anim Nutr Feed Technol 2014;14:311-9. https://doi. org/10.5958/0974-181X.2014.01327.4

40.Sunder GS, Kumar CV, Panda AK, Raju MVLN, Rama Rao SV. Effect of supplemental organic $\mathrm{Zn}$ and $\mathrm{Mn}$ on broiler performance, Bone measures, tissue mineral uptake and immune response at 35 days of age. Curr Res Poult Sci 2013;3:1-11. https://doi.org/10.3923/crpsaj.2013.1.11

41. Ma W, Niu H, Feng J, Wang Y, Feng J. Effects of zinc glycine chelate on oxidative stress, contents of trace elements, and intestinal morphology in broilers. Biol Trace Elem Res 2011; 142:546-56. https://doi.org/10.1007/s12011-010-8824-9 
42. Mohanna C, Nys Y. Effect of dietary zinc content and sources on the growth, body zinc deposition and retention, zinc excretion and immune response in chickens. Br Poult Sci 2010;40: 108-14. https://doi.org/10.1080/00071669987926

43. Pimentel JL, Cook ME, Greger JL. Research Note: Bioavailability of zinc-methionine for chicks. Poult Sci 1991;70:16379. https://doi.org/10.3382/ps.0701637

44. Yang XJ, Sun XX, Li CY, et al. Effects of copper, iron, zinc, and manganese supplementation in a corn and soybean meal diet on the growth performance, meat quality, and immune responses of broiler chickens. J Appl Poult Res 2011;20:263-71. https://doi.org/10.3382/japr.2010-00204

45. Badawi M, Ali M, Behairy A. Effects of zinc sources supplementation on performance of broiler chickens. J Am Sci 2017; 13:35-40.

46. Sajadifar S. Effect of dietary zinc level of zinc on performance and cecal lesion score in broilers infested with Eimeria tenella. Arch Zootec 2013;16:71-8.

47. Yogesh K, Deo C, Shrivastava HP, et al. Growth performance, carcass yield, and immune competence of broiler chickens as influenced by dietary supplemental zinc sources and levels. Agric Res 2013;2:270-4. https://doi.org/10.1007/s40003-0130067-5

48. Ibrahim D, Ali HA, El-Mandrawy SAM. Effects of different zinc sources on performance, bio distribution of minerals and expression of genes related to metabolism of broiler chickens. Zag Vet J 2017;45:292-304. https://dx.doi.org/10.21608/zvjz. 2017.7954

49.Lai PW, Liang JB, Hsia LC, Loh TC, Ho YW. Effects of varying dietary zinc levels and environmental temperatures on the growth performance, feathering score and feather mineral concentrations of broiler chicks. Asian-Australas J Anim Sci 2010;23:937-45. https://doi.org/10.5713/ajas.2010.90495

50. Ivanišinová O, Grešáková L, Ryzner M, et al. Effects of feed supplementation with various zinc sources on mineral concentration and selected antioxidant indices in tissues and plasma of broiler chickens. Acta Vet Brno 2016;85:285-91. https://doi.org/10.2754/avb201685030285

51.Ezzati MS, Bozorgmehrifard MH, Bijanzad P. Effects of different levels of zinc supplementation on broilers performance and immunity response to Newcastle disease vaccine. Eur J Exp Biol 2013;3:497-501.

52.St-Pierre NR. Integrating quantitative findings from multiple studies using mixed model methodology. J Dairy Sci 2001; 84:741-55.

53. Sauvant D, Schmidely P, Daudin JJ, St-Pierre NR. Meta-analyses of experimental data in animal nutrition. Animal 2008;2:120314. https://doi.org/10.1017/S1751731108002280

54.SAS Institute Inc. SAS/STAT Software version 9.1. Cary, NC, USA: SAS Institute Inc.; 2008.

55. Cui H, Xi P, Junliang D, Debing L, Guang Y. Pathology of lymphoid organs in chickens fed a diet deficient in zinc. Avian
Pathol 2004;33:519-24. https://doi.org/10.1080/030794504 00003528

56. Burns RB. Antibody production suppressed in the domestic fowl (gallus domesticus) by zinc deficiency. Avian Pathol 1983; 12:141-6. https://doi.org/10.1080/03079458308436156

57.Kidd MT, Ferket PR, Qureshi MA. Zinc metabolism with special reference to its role in immunity. World's Poult Sci J 1996;52:309-24. https://doi.org/10.1079/WPS19960022

58. Akter SH, Khan MZI, Jahan MR, Karim MR, Islam MR. Histomorphological study of the lymphoid tissues of broiler chickens. Bangladesh J Vet Med 2006;4:87-92.

59. Schat KA, Skinner MA. Avian immunosuppressive diseases and immune evasion. In: Schat KA, Kaspers B, Kaiser P, editors. Avian immunology. San Diego, CA, USA: Elsevier Ltd. Publishing; 2014. p. 275-97.

60. Tanaka YS, Shiozawa S, Morimoto I, Fujita T. Role of zinc in interleukin 2 (IL2) mediated T-cell activation. Scand J Immunol 1990;31:547-52. https://doi.org/10.1111/j.1365-3083.1990. tb02805.x

61. Olah I, Nagy N, Verwelde L. Structure of the avian lymphoid system. In: Schat KA, Kaspers B, Kaiser P, editors. Avian immunology 2nd Edition. San Diego, CA, USA: Elsevier Ltd. Publishing; 2014. p. 11-44.

62.Puvadolpirod S, Thaxton PJ. Model of physiological stress in chickens 1. Response parameters. J Poult Sci 2000;79:363-9. https://doi.org/10.1093/ps/79.3.363

63. Jeurissen $\mathrm{SH}$. The role of various compartments in the chicken spleen during an antigen-specific humoral response. Immunology 1993;80:29-33.

64. Smith KG, Hunt JL. On the use of spleen mass as a measure of avian immune system strength. Oecologia 2004;138:28-31. https://doi.org/10.1007/s00442-003-1409-y

65. Moller AP, Erritzoe J. Predation against birds with low immunocompetence. Oecologia 2000;122:500-4. https://doi.org/10. 1007/s004420050972

66. House WL, Wastney ME. Compartmental analysis of zinc kinetics in mature male rats. Am J Physiol 1997;273:R111725. https://doi.org/10.1152/ajpregu.1997.273.3.R1117

67. Jahanian R, Moghaddam HN, Rezaei A, Haghparast AR. The influence of dietary zinc-methionine substitution for zinc sulfate on broiler chick performance. J Biol Sci 2008;8:321-7. http://dx.doi.org/10.3923/jbs.2008.321.327

68. Ebrahimzadeh SK, Farhoomand P, Noori K. Immune response of broiler chickens fed diets supplemented with different level of chromium methionine under heat stress conditions. AsianAustralas J Anim Sci 2012;25:256-60. https://doi.org/10.5713/ ajas.2011.11217

69. Walsh CT, Sandstead HH, Prasad AS, Newberne PM, Fraker PJ. Zinc: health effects and research priorities for the 1990S. Environ Health Perspect 1994;102:5-46. https://doi.org/10.1289/ ehp.941025

70.Dardenne M, Savino W, Borrih S, Bach JF. A zinc dependent 
epitope of the molecule of thymulin, a thymic hormone. Proc Natl Acad Sci 1985;82:7035-8. https://doi.org/10.1073/pnas. 82.20.7035

71.Prasad AS, Meftah S, Abdallah J. Serum thymulin in human zinc deficiency. J Clin Invest 1988;82:1202-10. https://doi.org/ 10.1172/JCI113717

72. Gaither LA, Eide DJ. Eukaryotic zinc transporters and their regulation. Biometals 2001;14:251-70. https://doi.org/10.1023/ A:1012988914300

73. Andrews GK. Regulation of metallothionein gene expression by oxidative stress and metal ions. Biochem Pharmacol 2000; 59:95-104. https://doi.org/10.1016/S0006-2952(99)00301-9

74. Sandoval M, Henry PR, Luo XG, Littell RC, Miles RD, Ammerman CB. Performance and tissue zinc and metallothionein accumulation in chicks fed a high dietary level of zinc. Poult Sci 1998;77:1354-63. https://doi.org/10.1093/ps/77.9.1354

75. Wedekind KJ, Hortin AE, Baker DH. Methodology for assessing zinc bioavailability: efficacy estimates for zinc-methionine, zinc sulfate, and zinc oxide. J Anim Sci 1992;70:178-87. https:// doi.org/10.2527/1992.701178x

76. Ebuehi OAT, Akande GA. Effect of zinc deficiency on memory, oxidative stress and blood chemistry in rats. Int J Biol Chem Sci 2009;3:513-23.

77.Canada AT, Calabrese EJ. Superoxide dismutase: Its role in xenobiotic detoxification. Pharmacol Ther 1989;44:285-95. https://doi.org/10.1016/0163-7258(89)90068-5

78. Yuan J, Xu Z, Huang C, et al. Effect of dietary Mintrex-Zn/Mn on performance, gene expression of $\mathrm{Zn}$ transfer proteins, activities of $\mathrm{Zn} / \mathrm{Mn}$ related enzymes and fecal mineral excretion in broiler chickens. Anim Feed Sci Technol 2011;168:72-9. https://doi.org/10.1016/j.anifeedsci.2011.03.011

79. Noor R, Mittal S, Iqbal J. Superoxide dismutate: applications and relevance to human disease. Med Sci Monit 2002;8:RA210-5.

80.Zago MP, Oteiza PI. The antioxidant properties of zinc: interactions with iron and antioxidants. Free Radic Biol Med 2001; 31:266-74. https://doi.org/10.1016/S0891-5849(01)00583-4

81. Ozturk A, Baltaci K, Mogulkoc R, et al. Effects of zinc deficiency and supplementation on malondialdehyde and glutathione levels in blood and tissues of rats performing swimming exercise. Biol Trace Elem Res 2003;94:157-66. https:/doi.org/ 10.1385/BTER:94:2:157

82. Tupe RS, Tupe SG, Tarwadi KV, Agte VV. Effect of different dietary zinc levels on hepatic antioxidant and micronutrients indices under oxidative stress conditions. Metabolism 2010; 59:1603-11. https://doi.org/10.1016/j.metabol.2010.02.020

83. Bao YM, Choct M, Iji PA, Bruerton K. Optimal dietary inclusion of organically complexed zinc for broiler chickens. $\mathrm{Br}$ Poult Sci 2009;50:95-102. https://doi.org/10.1080/00071660 802590377

84. Prasad AS, Kucuk O. Zinc in cancer prevention. Cancer Metastasis Rev 2002;21:291-5. https://doi.org/10.1023/A:1021215 111729
85. Raharjo S, Sofos JN. Methodology for measuring malonaldehyde as a product of lipid peroxidation in muscle tissues: a review. Meat Sci 1993;35:145-69. https://doi.org/10.1016/03091740(93)90046-K

86. Powell SR. The antioxidant properties of zinc. J Nutr 2000;130: 1447S-54S. https://doi.org/10.1093/jn/130.5.1447S

87. Tate DJ, Miceli MV, Newsome DA. Zinc protects against oxidative damage in cultured human retinal pigment epithelial cells. Free Radic Biol Med 1999;26:704-13. https://doi.org/ 10.1016/S0891-5849(98)00253-6

88. Yamaguchy S. The role of SOD antioxidant. J Natl Cancer Inst 1991;28:221-32.

89. Gibbs PN, Gore MG, Jordan PM. Investigation of the effect of metal ions on the reactivity of thiol groups in human 5-aminolaevulinate dehydratase. Biochem J 1985;225:573-80. https:// doi.org/10.1042/bj2250573

90. Beach RS, Gershwin ME, Makishima RK, Hurley LS. Impaired immunologic ontogeny in postnatal zinc deprivation. J Nutr 1980;110:805-15. https://doi.org/10.1093/jn/110.4.805

91. Yang W, Chen Y, Cheng Y, Wen C, Zhou Y. Effects of zinc bearing palygorskite supplementation on the growth performance, hepatic mineral content, and antioxidant status of broilers at early age. Asian-Australas J Anim Sci 2017;30:100612. https://doi.org/10.5713/ajas.16.0551

92. Foltz KL, Glover BG, Moritz JS. Effect of supplemental zinc source and corn particle size on 40-day broiler performance. J Appl Poult Res 2017;26:209-18. https://doi.org/10.3382/japr/ pfw064

93.Zakaria HA, Jalal M, AL-Titi HH, Souad A. Effect of sources and levels of dietary zinc on the performance, carcass traits and blood parameters of broilers. Braz J Poult Sci 2017;19: 519-26. http://dx.doi.org/10.1590/1806-9061-2016-0415

94.El-Husseiny OM, Hashish SM, Ali RA, Arafa SA. Effects of feeding organic zinc, manganese and copper on broiler growth, carcass characteristics, bone quality and mineral content in bone, liver and excreta. Int J Poult Sci 2012;11:368-77. http:// dx.doi.org/10.3923/ijps.2012.368.377

95. Kim WK, Patterson PH. Effects of dietary zinc supplementation on broiler performance and nitrogen loss from manure. Poult Sci 2004;83:34-8. https://doi.org/10.1093/ps/83.1.34

96. Pathak SS, Reddy KV, Prasoon S. Influence of different sources of zinc on growth performance of dual purpose chicken. J Bio Innov 2016;5:663-72.

97. Oberleas D, Muhrer ME, O’Dell BL. Dietary metal-complexing agents and zinc availability in the rat. J Nutr 1966;90:5662. https://doi.org/10.1093/jn/90.1.56

98. O'dell BL, Yohe JM, Savage JE. Zinc Availability in the chick as affected by phytate, calcium and ethylenediaminetetraacetate. Poult Sci 1964;43:415-9. https://doi.org/10.3382/ps. 0430415

99. Ghosh A, Mandal GP, Roy A, Patra AK. Effects of supplementation of manganese with or without phytase on growth per- 
formance, carcass traits, muscle and tibia composition, and immunity in broiler chickens. Livest Sci 2016;191:80-5. https:// doi.org/10.1016/j.livsci.2016.07.014

100. Attia YA, Qota EM, Bovera F, Tag El-Din AE, Mansour SA. Effect of amount and source of manganese and/or phytase supplementation on productive and reproductive performance and some physiological traits of dual purpose cross-bred hens in the tropics. Br Poult Sci 2010;51:235-45. https://doi.org/10. 1080/00071661003786111

101. Brody T. Nutritional Biochemistry. New York, USA: Academic Press; 1994.

102. McDowell LR. Minerals in animal and human nutrition. New York USA: Academic Press Inc; 2003.

103. Liu ZH, Lu L, Li SF, et al. Effects of supplemental zinc source and level on growth performance, carcass traits, and meat quality of broilers. Poult Sci 2011;90:1782-90. https:/doi.org/ 10.3382/ps.2010-01215

104. Liu ZH, Lu L, Wang R, et al. Effects of supplemental zinc source and level on antioxidant ability and fat metabolismrelated enzymes of broilers. Poult Sci 2015;94:2686-94. https:// doi.org/10.3382/ps/pev251

105. Ferrini G, Manzanilla EG, Menoyo D, Esteve-Garcia E, Baucells MD, Barroeta AC. Effects of dietary n-3 fatty acids in fat metabolism and thyroid hormone levels when compared to dietary saturated fatty acids in chickens. Livest Sci 2010;131:287-91. https://doi.org/10.1016/j.livsci.2010.03.017

106. Sartika RAD. Effects of saturated, unsaturated fatty acids and trans fatty acids on health. Kesmas 2008;2:154-60.

107. Harland BF, Fox MRS, Fry BE. Changes in plasma zinc related to fasting and dietary protein intake of Japanese quail. Proc Soc Exp Biol Med 1974;145:316-22. https://doi.org/10.3181/ 00379727-145-37801

108. Casey CE, Walravens PA, Hambridge KM. Zinc absorption and plasma response. Am J Clin Nutr 1981;34:1443-4. https:// doi.org/10.1093/ajcn/34.7.1443

109. Littell RC, Henry PR, Lewis AJ, Ammerman CB. Estimation of relative bioavailability of nutrients using SAS procedures. J Anim Sci 1997;75:2672-83. https://doi.org/10.2527/1997. $75102672 \mathrm{x}$

110. Grynpas MD, Pritzker KPH, Hancock RGV. Neutron activation of bulk and selected trace elements in bone using a low flux slowpoke reactor. Biol Trace Elem Res 1987;13:333-44. https://doi.org/10.1007/BF02796644

111. Attia YA, Abd Al-Hamid AE, Zeweil HS, et al. Effect of dietary amounts of inorganic and organic zinc on productive and physiological traits of White Pekin ducks. Animal 2013;7:895900. https://doi.org/10.1017/S1751731113000050

112. Loveridge N. Micronutrients and longitudinal growth [internet]. The Proceedings of the Nutrition Society 1993 [cited 2018 Des 20]. Available from: https://www.cambridge.org/ core/services/aop-cambridge-core/content/view/1A864F9C A106A74849248198CDDD3E4F/S0029665193000102a. pdf/micronutrients_and_longitudinal_growth.pdf

113. Wang Z, Cerrate S, Coto C, et al. Evaluation of Mintrex copper as a source of copper in broiler diets. Int J Poult Sci 2007;6:308-13. http://dx.doi.org/10.3923/ijps.2007.308.313

114. Alibaba. Zinc methionine feed additive [Internet]. 19992019 Alibaba.com [cited 2019 Apr 12]. Available from: https:// www.alibaba.com/product-detail/zinc-methionine-exportingto-Japan-Feed_486677274.html?spm=a2700.7724857.nor malList.17.285075e6kodP2y

115. Alibaba. Nutritional feed additive zinc sulphate monohydrate [Internet]. 1999-2019 Alibaba.com [cited 2019 Apr 12]. Available from: https://www.alibaba.com/product-detail/nutritionalfeed-additive-zinc-sulphate-monohydrate_62056219351. html?spm=a2700.7724857.normalList.12.3cb536a8y8OCeu $\& \mathrm{~s}=\mathrm{p}$

116. Berger LL. Trace minerals In: Cunha TJ. Salt and trace minerals for livestock, poultry and other animals [Internet]. Alexandria: Salt Institute 2006; p. 63-64 [cited 2018 August 26 ]. Available from: http://citeseerx.ist.psu.edu/viewdoc/down load?doi=10.1.1.467.8193\&rep=rep1\&type $=$ pdf

117. Salim HM, Lee HR, Jo C, et al. Effect of source sand levels of $\mathrm{Zn}$ on the tissue mineral concentration and carcass quality of broilers. Avian Biol Res 2010;3:23-9.

118. Burrell AL, Dozier WA, Davis AJ, et al. Responses of broilers to dietary zinc concentrations and sources in relation to environmental implications. Br Poult Sci 2004;45:225-63. https://doi.org/10.1080/00071660410001715867

119. Zhang F, Li Y, Yang M, Li W. Content of heavy metals in animal feeds and manures from farms of different scales in Northeast China. Int J Environ Res Piublic Health 2012;9:265868. https://doi.org/10.3390/ijerph9082658

120. Giordano PM, Mortvedt JJ, Mays DA. Effect of Municipal wastes on crop yields and uptake of heavy metals. J Environ Qual 1975;4:349-99. https://doi.org/10.2134/jeq1975.00472 425000400030024x

121. Feng M, Wang ZS, Zhou AG, et al. The effects of different sizes of nanometer zinc oxide on the proliferation and cell integrity of mice duodenum-epithelial cells in primary culture. Pak J Nutr 2009;8:1164-6. http://dx.doi.org/10.3923/pjn.2009. 1164.1166

122. Rayani TF, Mutia R, Sumiati. Supplementation of zinc and vitamin $\mathrm{E}$ on apparent digestibility of nutrient, carcass traits, and mineral availability in broiler chickens. Trop Anim Sci J 2017;40:20-7. https://doi.org/10.5398/medpet.2017.40.1.20

123. Wang X, Fosmire GJ, Gay CV, Leach RM Jr. Short-term zinc deficiency inhibits chondrocyte proliferation and induces cell apoptosis in the epiphyseal growth plate of young chickens. J Nutr 2002;132:665-73. https://doi.org/10.1093/jn/132.4.665

124. Sarvari BG, Seyedi AH, Shahryar HA, Sarikhan M, Ghavidel SZ. Effects of dietary zinc oxide and a blend of organic acids on broiler live performance, carcass traits and serum parameters. Braz J Poult Sci 2015;17:39-46. http://dx.doi.org/10. 
1590/1516-635XSPECIALISSUENutrition-PoultryFeeding Additives039-046

125. Barman C, Goswami J, Sameh BC. Effect of zinc supplementation on feed consumption and growth performance of broiler chicks. Indian Vet J 2009;86:1154-5.

126. Kommera SK, Mateo RD, Neher FJ, Kim SW. Phytobiotics and organic acids as potential alternatives to the use of anti- biotics in nursery pig diets. Asian-Australas J Anim Sci 2006; 19:1784-9. https://doi.org/10.5713/ajas.2006.1784

127. Walker HK, Hall WD, Hurst JW, et al. Clinical methods: the history, physical and laboratory examination [Internet]. c1990 [cited 2018 August 16]. Available from: https://www.ncbi. nlm.nih.gov/pubmed/21250045 